\title{
IMPACT OF CURRENT ACCOUNT GAPS ON INFLATION IN SOUTH ASIAN COUNTRIES
}

\author{
Sardar Shakeel Ahmad ${ }^{\text {* }}$, Atif Ali Jaffri' ${ }^{2}$, Faisal Rana ${ }^{3}$, Asadullah Khan ${ }^{4}$ \\ ${ }^{1 *, 2}$ Department of Economics, University of Gujrat, Pakistan; ${ }^{3}$ School of Business Administration, American University \\ in Dubai, Dubai, United Arab Emirates; ${ }^{4}$ Department of Business Management, Karakoram International University, \\ Gilgit, Pakistan. \\ Email: ${ }^{*}$ s_shakil_ahmad@yahoo.com
}

Article History: Received on $8^{\text {th }}$ June 2021, Revised on $17^{\text {th }}$ June 2021, Published on $21^{\text {st }}$ June 2021

\begin{abstract}
Purpose of the study: The current study estimated the impact of current account gaps (CAGAP) on inflation in South Asian countries, namely, Pakistan, Bangladesh, India, Nepal, and Sri Lanka.

Methodology: CAGAP is estimated through macroeconomic fundamentals by applying panel time series data methodology from 1990 to 2018. We adopted the bias-corrected least square dummy variable (LSDVC) estimation technique for the time series macro and dynamic panel to find the impact of CAGAP on inflation.

Principal findings: CAGAP negatively affected consumer price inflation rate while Lag of inflation, trade openness, age dependency, and oil prices positively affected inflation rate in the selected sample countries. In LSDVC, the Blundell and Bond (BB), Arellano-Bond (AB), Anderson and Hsiao (AH) estimates are determined while system and difference GMM estimates also confirmed the results. Therefore, LSDVC-AB is selected from the three versions of LSDVC as baseline regression based on higher significance and lower standard error.

Applications of the Study: CAGAP affects inflation, so it should be estimated annually in all these countries for macroeconomic stability as IMF annually estimates for developed countries in an external sector report. It is worthwhile to estimate CAN regularly and watch it for $\mathrm{CAB}$ evaluation and future Adjustment. Based on the results, the study recommends that tailored policies and interventions focus on the structural distortions and slow-changing factors to eradicate CAGAP.
\end{abstract}

Novelty/ Originality of the Study: A few empirical studies have scrutinized the role of $\mathrm{CAB}$ on macroeconomic variables. No empirical study on CAGAP and its consequences are available in the selected region's existing literature to the best of our knowledge.

Keywords: Current Account Balance, Current Account Gap, Inflation Rate, South Asia, Time Series Panel.

\section{INTRODUCTION}

An economy's ability to finance imports and payments of services, income (e.g., interest payments), and transfers through receipts from exports of goods, services, income (e.g., profit remittances), and transfers (e.g., worker remittances) can be reflected through current account balance (CAB). CAB may be a source of concern when two conditions hold in CA Norms: (a) when structural variables are dominant rather than cyclical, for example, when export earnings are unable to cover imports and debt service obligations over the foreseeable future; and (b) When financing of CAGAP depends on short-term external borrowing or a protracted reduction in official reserves or other net foreign assets. (Greene, 2018). A sustainable current account deficit (CAD) may be possible through high-interest rates, which can increase capital inflows and dampen consumption and investment and increase savings wou, leading I It can be improved by increasing domestic savings and lowering government borrowing with an increase in taxes (Al-Eyd, Barrell, \& Pomerantz, 2005). That's why the Adjustment of CAD would be contractionary in demand, inflation, and output growth in the economy.

CAGAP does not matter if it is aligned to macroeconomic fundamentals. Otherwise, it may have a critical impact on macroeconomic variables (Gnimassoun and Magnon, 2013; Lane \& Milesi-Ferretti, 2014; \& Comunale, (2017). CAGAP may create an external crisis, vulnerability to sudden stop, exchange rate collapse, and economic slowdown Cusolito and Nedeljkovic (2013). For example, CAGAP adjustment after the financial crisis in 2008 confirmed that the exchange rate depreciated to stabilize the external position. As a result, there was a drastic decline in demand and output in high CAD countries (Lane et al., 2014). ${ }^{1}$

CAGAP affects macroeconomic variables through these possible channels (a) CAGAP causes depreciation of the domestic currency, making the imports of raw material, semi-finished products, and capital goods expensive. Cost of production and price level rises in the home country due to this supply channel (Yurdakula \& Ucar, 2015), (b) CAGAP through exchange rate depreciation may also shift the aggregate demand up due to an increase in competitiveness. Wages, price level, and output level rise due to this demand channel. The net effect is decided based on demand and supply channels $\underline{\text { Dincer \& Kandil, 2011). }}$ 
The rationale of the study and Objective: The selected countries are experiencing the same pattern of sectoral transformation from agriculture to services with incomplete industrialization (Jha and Afrin, 2018), and the region is exposed to macroeconomic vulnerabilities from both domestic and external factors. Fiscal deficit, saving investment gap, robust growth of credit to the private sector, and the pressure of external obligations and internal economic issues in the coming years are the common problems almost in the whole region (South Asia Regional Update IMF, 2018). It is expected that headline inflation in most of the economies will remain under control, owing to good food inflation. But, in Pakistan, it is currency depreciation and energy tariff causing inflation. Bangladesh and India have moderated CAD, but it continued to pose macroeconomic challenges for Nepal and Pakistan. According to the World Bank's regional report on the South Asian economies (2019), it is very important to know the root cause of the CAGAP and then eliminate this gap. The current study estimated the impact of CAGAP on inflation in the selected region, while CAGAP is estimated from macroeconomic fundamentals through Macroeconomic Balance Approach (MB) approach $^{2}$.

\section{LITERATURE REVIEW}

The comprehensive review on inflation in selected South Asian countries can be divided into three strands: The first strand covers the approaches to estimate CAGAP. The inclusive review of the first strand shows that Rahman (2008), Medina, Prat, \& Thomas (2010), and Comunale (2015) used the MB Methodology of IMF for the measurement of CAN. The second strand estimated the impact of domestic and external factors on inflation. Yoon, Kim, and Le (2014) empirically found that population growth, old-age dependency (65 and above), working-age population, and life expectancy affected inflation. Freund and Warnock (2005) investigated that the larger CAD in industrial countries, the harder they adjust. The size, persistence, consumption-driven deficit, and the dependence on debt inflows raise concerns about Adjustment. Al-Eyd et al. (2005) explored the empirical link between US CAD adjustment and the dollar exchange rate realignment. This study explained that CAD might be due to the exchange rate movement above sustainable level, structural imbalance in the economy, and profitable domestic investment. The study concluded that domestic demand and the exchange rate would slide downward in the adjustment process. Holinski, Kool, and Muysken (2012) documented a growing divergence between CA imbalances in northern and southern euro area countries from 1992 to 2007. The adjustment costs will be high in the absence of sufficient market-based adjustment mechanisms and negative consequences for fiscal policy. Wright (2013) estimated critical factors that affected CAB's sustainable level CAB, including NFA to GDP ratio, Fuel to GDP ratio, relative productivity g, growth, and labor force participation rate. The study further added that, firstly, the misalignment of the exchange rate would be corrected through the fundamentals from which it is calculated. Secondly, price competitiveness is not the only factor. Still, the structural factors are more responsible for the CAB'sd and sustainable level of Khan \& Islam (2013) \& Tung, Thanh \& Thang (2015) found that remittance inflows positively and significantly impact inflation. Trabelsi (2016) estimated that globalization negatively affects inflation in the 34 OECD economies using the macro panel's econometric technique and data period from 1998 to 2015.

The third strand covers the impact of CAGAP on inflation that has been the less focused area. Borensztein and Gregorio $\underline{(1999)}$ empirically explored the link between exchange rate misalignment, CAD, and inflation using a sample of currency crises throughout 1970-1996. The study further found that output gap, real exchange rate misalignment, and $\mathrm{CAB}$ are significant determinants of inflation. Lane et al. (2012) \& Lane et al. (2014) confirmed empirically that the Adjustment of CAGAP expenditure switching policy played a limited role while there is a drastic change in aggregate demand and output level. Finally, Comunale (2017) empirically studied that CAGAP affected the currency misalignment, affecting the imports of raw material, final commodities, and export prices. As a result, domestic inflation rises due to the process mentioned above. The study concluded that the internal devaluation of the domestic currency rectified the misalignment in the exchange rate, which improves external competitiveness.

\section{RESEARCH METHODOLOGY}

By following the literature on inflation (Kamin, 1997; Marc \& Kalau, 1998; Jaffri, 2010), the model developed as follows

$$
I N F_{t}=\beta_{0}+\beta_{1} I N F_{t}^{d}+\beta_{2} I N F_{t}^{*}+\beta_{3} \Delta E R_{t}+\mu_{t}
$$

According to Marc and Kalau (1998) and Comunale (2017), we can use the following relationship,

$$
I N F_{t}^{d}=f\left(E R-E R^{*}\right)_{t-1}=f\left(C A B-C A B^{*}\right)_{t-1}
$$

CAGAP, exchange rate, and economic growth are economically linked to one another, and it is undeniable that currency misalignment arises from internal and external imbalances (Gnimassoun et al., 2013 and Comunale, 2017). Since

$$
C A B-C A B^{*}=C A G A P=\text { Actual } C A B-C A \text { Norms }
$$

Therefore, by using the above relationships and putting in (A) for panel data

\footnotetext{
${ }^{2}$ See Lane \& Milesi-Ferretti (2014).
} 


$$
\begin{gathered}
I N F_{i t}=\beta_{1}+\beta_{2} I N F_{i t-1}+\beta_{3} C A G A P_{i t}+\beta_{4} A D_{i t}+\beta_{5} M S_{i t}+\beta_{6} O P i t+\beta_{7} T O_{i t} \\
+\beta_{8} I N V_{i t}+\varepsilon_{i t}
\end{gathered}
$$

Where $\mathrm{INF}_{\mathrm{it}-1}$ shows Lag of consumer inflation where 'ii' shows cra oss section, "tt' is a time dimension, $\mathrm{CAGAP}_{\mathrm{it}}$ is current account gap, $A D_{i t}$ is the age dependency, $M S_{i t}$ is the money supply, it's the trade openness, $\mathrm{INV}_{\mathrm{it}}$ is the investment rate, ${ }_{i t}$ is the oil price, and $\mu_{\mathrm{it}}$ is the error term. The following section has theoretical channels.

The consumer price index covers many items of daily use, so it is considered a better measure of price changes from the consumer point of view. The annual average growth rate of CPI is taken as the proxy of the inflation rate because it is used in the empirical literature (e.g., Khan, Bukhari, and Ahmad, 2007). A country will face price persistence if the majority of firms adjust their prices based on past information. The introduction of inflation lag fits the data better than the forwarding-looking model (Sbordone, 2007). The First Lag of inflation is used in the model to introduce persistence. According to Lane et al. (2014), positive CAGAP undergo a greater pressure for appreciation of the domestic currency and the relative decline in the aggregate demand that will ultimately hurt the inflation rate. The study used the deviation of $\mathrm{CAB}$ from $\mathrm{CAN}$ as the main independent variable of the study to estimate its impact.

The pattern of change in population size and age structure affect aggregate demand and supply agents, inflation expectations, and assets price (Khan, Khan, Ullah, Usman, Farhat, 2020). The study used age dependency as a proxy of demographic factors in the panel. New growth theory explained that trade openness works through (a) efficiency, (b) best resources allocation, (c) improved capacity utilization, and (d) foreign investment that increases output and ultimately reduces inflation. However, Ullah, Shaikh, Channar, \& Shaikh (2021) invalidates Romer's (1993) proposition and find a symmetric and positive relationship between trade openness and inflation. We, therefore, wee used X+M/GDP in perc. According to Pyhrr, Born, and Webb (1990), real and financial investment is always affected by the inflation and inflation cycles. These cycles have a complex impact on cash flow variables and thus on investment. Therefore, we used total investment as a percent of GDP as the control variable. The money supply does not necessarily cause inflation (Shaikh, Channar, \& Shaikh, Ullah, (2021). The total amount of monetary assets available in an economy at a specific point in time is the money supply. This study has taken M2 as a percentage of GDP as the control variable in the model. The production and commodities prices in the region show transmission of any change in oil prices at the international level. Jaffri et al. (2012) showed that any rise in oil price at the international level would affect the domestic price stability. In this study, we have used Crude Oil (petroleum), a simple average of three spot prices; Dated Brent, West Texas Intermediate, and the Dubai Fateh, US\$ per barrel.

\section{Selection of Empirical Technique}

The current study was inspired by Judson and Owen (1996) \& Sung \& Park (2018) for the estimation technique for the dynamic macro panel. Fixed effect (LSDV) estimates are consistent only in the static model, but these estimates have a non-negligible bias in the dynamic panel data model. According to Baltagi (2008), pooled OLS estimators are biased upward while FEM estimators are biased downward concerning econometric assumptions. Moreover, difference GMM estimators of the lagged dependent variable are strongly downward biased (Blundell and Bond, 2002). The GMM estimates cannot be used in macro panels as their properties hold when cross-section $(\mathrm{N})$ is greater than period (T). That is why their estimates can be severely biased and imprecise when $\mathrm{N}$ is less than $\mathrm{T}$.

According to Judson et al. (1996), LDVC may be far better than GMM in dynamic macro panels, and they also recommend three versions of bias-corrected least squares dummy variables (LSDVC) in the form of (a) AH instrument variable (b) $\mathrm{AB}$ and (c) $\mathrm{BB}$ estimates. After estimation with different regression techniques, diagnostics are applied. First, the condition of no correlation in the error term is introduced in the dynamic panel model (Cameron and Trivedi, 2009). Second, Arellano and Bond test for serial correlation are applied, and the expected P-value of the AR (1) test should be significant $(\operatorname{Pr}<0.05)$ while the P-value of AR (2) should be insignificant $(\operatorname{Pr}>0.05)$. Finally, the Sargan Test of over-identifying restriction is applied. The over-identifying restriction is about the correlation between the error term and instruments, and the null hypothesis should be insignificant.

\section{RESULTS}

Descriptive statistics are imperative to observe the variability and distribution of the data series for further analysis. There are 145 observations for each variable for each country, i.e., it is strong, balanced data. See Table 1 for Descriptive Statistics and Table 2 for pairwise correlation coefficients. Pairwise correlation analysis showed that INF is significantly correlated with CAGAP, and too as the asterisk $(*)$ shows that p-value $<0.05$.

The following way is used for the empirical analysis in the panel context: The characteristics of the data have been confirmed before establishing the empirical model and application of LSDVC in the final phase, like (a) the presence of autocorrelation, (b) multicollinearity between explanatory variables, (c) multicollinearity in the panels, (d) crosssectional dependence between cross-sectional units, (e) homoscedasticity within cross-sections and (f) endogeneity in the panel.

Table 1: Descriptive Statistics and Comparison

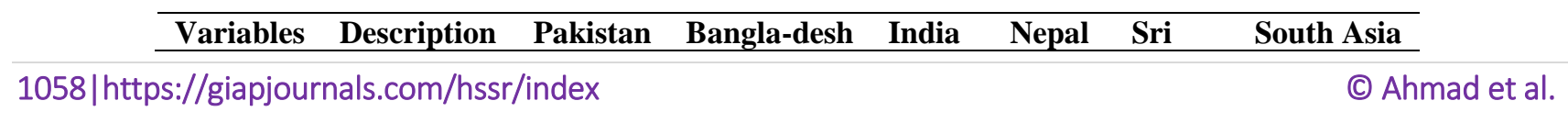




\begin{tabular}{llllllll}
\hline & & & & & 3 & Lanka \\
\hline INF & Maximum & 20.29 & 11.33 & 13.87 & 17.15 & 22.56 & 22.56 \\
\cline { 2 - 8 } & Minimum & 2.53 & 2.01 & 3.33 & 2.27 & 2.14 & 2.01 \\
\cline { 2 - 8 } & Mean & 8.367 & 6.142 & 7.479 & 7.532 & 9.239 & 7.75 \\
\cline { 2 - 8 } & S. Deviation & 4.162 & 2.310 & 3.192 & 3.693 & 5.055 & 3.883 \\
\hline CAGAP & Maximum & 7.244 & 3.873 & 3.853 & 9.849 & 0.3912 & 9.85 \\
\cline { 2 - 8 } & Minimum & -6.133 & -3.587 & -2.482 & -7.481 & -8.691 & -8.69 \\
\cline { 2 - 8 } & Mean & 0.490 & -0.004 & 0.805 & 0.177 & -2.669 & -0.240 \\
\cline { 2 - 8 } & S. Deviation & 2.869 & 1.773 & 1.387 & 3.172 & 2.134 & 2.644 \\
\hline AD & Maximum & 88.87 & 83.3379 & 71.695 & 85.04 & 60.18 & 88.87 \\
& Minimum & 64.37 & 49.1605 & 50.537 & 56.607 & 48.00 & 48.00 \\
\cline { 2 - 8 } & Mean & 76.50 & 65.356 & 61.16 & 75.39 & 51.50 & 65.98 \\
\cline { 2 - 8 } OP & S. Deviation & 9.218 & 10.318 & 6.81 & 8.89 & 3.671 & 12.30 \\
& Maximum & 2.02 & 2.02 & 2.02 & 2.02 & 2.02 & 2.02 \\
\cline { 2 - 8 } & Minimum & 1.12 & 1.12 & 1.12 & 1.12 & 1.12 & 1.12 \\
\cline { 2 - 8 } & Mean & 1.578 & 1.578 & 1.578 & 1.578 & 1.578 & 1.578 \\
\cline { 2 - 8 } TO & S. Deviation & 0.293 & 0.293 & 0.293 & 0.293 & 0.293 & 0.293 \\
\cline { 2 - 8 } & Maximum & 38.91 & 48.11 & 55.79 & 64.04 & 88.64 & 88.64 \\
\cline { 2 - 8 } & Minimum & 25.31 & 18.89 & 15.67 & 32.19 & 46.36 & 15.67 \\
\cline { 2 - 8 } INV & Mean & 33.01 & 33.05 & 35.40 & 48.69 & 67.09 & 43.45 \\
\cline { 2 - 8 } & S. Deviation & 3.740 & 8.771 & 13.18 & 7.07 & 13.24 & 16.43 \\
\cline { 2 - 8 } & Maximum & 20.821 & 31.59 & 39.59 & 51.756 & 39.056 & 51.756 \\
\cline { 2 - 6 } & Mean & 14.121 & 17.508 & 21.8 & 16.884 & 23.197 & 14.121 \\
\cline { 2 - 8 } & S. Deviation & 1.807 & 4.004 & 5.616 & 9.000 & 3.910 & 7.147 \\
& & & & & & &
\end{tabular}

Table 2: Correlation Matrix of Variables

\begin{tabular}{llllllll}
\hline & INF & CAGAP & AD & MS & OP & TO & INV \\
\hline INF & 1.000 & & & & & & \\
\hline CAGAP & $-0.226^{*}$ & 1.000 & & & & & \\
\hline AD & 0.004 & $0.268^{*}$ & 1.000 & & & & \\
\hline MS & -0.110 & $0.249^{*}$ & $-0.272^{*}$ & 1.000 & & & \\
\hline OP & 0.012 & -0.027 & $-0.497^{*}$ & $0.585^{*}$ & 1.000 & & \\
\hline TO & $0.230^{*}$ & $-0.381^{*}$ & $-0.485^{*}$ & 0.013 & 0.091 & 1.000 & \\
\hline INV & -0.049 & $-0.236^{*}$ & $-0.621^{*}$ & $-0.551^{*}$ & $0.444^{*}$ & $0.442^{*}$ & 1.000 \\
\hline
\end{tabular}

Table 3: Model Specification Tests

\begin{tabular}{|c|c|c|c|c|c|}
\hline \multicolumn{2}{|c|}{ Model Specification Test } & \multicolumn{2}{|c|}{ Test Statistics } & P-Values & Decision \\
\hline \multicolumn{2}{|c|}{$\begin{array}{l}\text { Cross-Section Dependence } \\
\text { H0: Cross- section Independence }\end{array}$} & \multicolumn{2}{|c|}{ Chi2 $(10)=13.453$} & 0.1994 & Cross-section Independence \\
\hline \multicolumn{2}{|c|}{ Multicollinearity Test (VIF) } & \multicolumn{2}{|c|}{ Mean Value $=2.02$} & & No Multicollinearity \\
\hline \multicolumn{2}{|c|}{$\begin{array}{l}\text { Specification Test } \\
\text { H0: Model has no omitted variables }\end{array}$} & \multicolumn{2}{|c|}{$\mathrm{F}(3,129)=0.18$} & 0.9069 & No Omitted Variables \\
\hline \multicolumn{2}{|c|}{$\begin{array}{l}\text { Autocorrelation test } \\
\text { H0: No First Order Autocorrelation }\end{array}$} & \multicolumn{2}{|c|}{$F(1,4)=82.426$} & 0.0008 & Dynamic Models \\
\hline \multicolumn{4}{|c|}{$\begin{array}{l}\text { (b) Durbin-Wu-Hausman test } \\
\text { H0: } \mathrm{E}\left(X_{i t}, \varepsilon_{i t}\right)=0\end{array}$} & 0.005 & LSDVC \\
\hline $\begin{array}{l}\text { Explanatory } \\
\text { Variables }\end{array}$ & $\begin{array}{l}\text { LSDV } \\
\text { (Dynamic) }\end{array}$ & $\begin{array}{l}\text { LSDVC } \\
\text { (AH) }\end{array}$ & $\begin{array}{l}\text { LSDVC } \\
\text { (AB) }\end{array}$ & $\begin{array}{l}\text { LSDVC } \\
\text { (BB) }\end{array}$ & \\
\hline $\mathrm{INF}_{\mathrm{t}-1}$ & $\begin{array}{l}0.39 * * * \\
(0.075)\end{array}$ & $\begin{array}{l}0.47 * * * \\
(0.077)\end{array}$ & $\begin{array}{l}0.47^{* * * *} \\
(0.077)\end{array}$ & $\begin{array}{l}0.48^{* * *} \\
(0.077)\end{array}$ & \\
\hline CAGAP & $\begin{array}{l}-0.29 * * \\
(0.128)\end{array}$ & $\begin{array}{l}-0.29^{* *} \\
(0.144)\end{array}$ & $\begin{array}{l}-0.28^{* *} \\
(0.130)\end{array}$ & $\begin{array}{l}-0.28 * * \\
(0.132)\end{array}$ & \\
\hline MS & $\begin{array}{l}0.02 \\
(0.042)\end{array}$ & $\begin{array}{l}0.03 \\
(0.047)\end{array}$ & $\begin{array}{c}0.02 \\
(0.042)\end{array}$ & $\begin{array}{l}0.03 \\
(0.043)\end{array}$ & \\
\hline $\mathrm{AD}$ & $\begin{array}{l}0.15^{* *} \\
(0.070)\end{array}$ & $\begin{array}{l}0.14 * * \\
(0.069)\end{array}$ & $\begin{array}{l}0.14^{* *} \\
(0.064)\end{array}$ & $\begin{array}{l}0.15^{* *} \\
(0.070)\end{array}$ & \\
\hline OP & $\begin{array}{l}0.07 * * \\
(1.527)\end{array}$ & $\begin{array}{l}3.18^{* *} \\
(1.592)\end{array}$ & $\begin{array}{l}3.31 * * \\
(1.435) \\
\end{array}$ & $\begin{array}{l}3.46^{* *} \\
(1.514)\end{array}$ & \\
\hline
\end{tabular}




\begin{tabular}{lllll}
\hline TO & $0.06^{*}$ & 0.064 & $0.06^{*}$ & $0.06^{*}$ \\
& $(0.034)$ & $(0.041)$ & $(0.033)$ & $(0.035)$ \\
\hline INV & -0.11 & -0.09 & -0.11 & -0.11 \\
& $(0.082)$ & $(0.092)$ & $(0.078)$ & $(0.080)$ \\
\hline Observation & 145 & 145 & 145 & 145 \\
\hline
\end{tabular}

Table 4: Diagnostics

\begin{tabular}{|c|c|c|}
\hline Diagnostics Arellano-Bond (AB) Estimates & & \\
\hline $\begin{array}{l}\text { (a): Sargan Test of over-identifying restriction, } \\
\text { Ho: } \mathrm{E}\left(\varepsilon_{i}, \mathrm{IV}\right)=0\end{array}$ & $\mathrm{Chi}^{2}(377)=121.49$ & 1.0000 \\
\hline $\begin{array}{l}\text { (b): Arellano-Bond test for (AR1) } \\
\text { (Ho: No Autocorrelation) }\end{array}$ & $Z=-5.34$ & 0.0000 \\
\hline $\begin{array}{l}\text { (c): Arellano-Bond test for (AR2) } \\
\text { (Ho: No Autocorrelation) }\end{array}$ & $Z=-0.92$ & 0.3571 \\
\hline
\end{tabular}

\section{DISCUSSIONS}

LSDVC estimators are preferred when they are compared with the original LSDV and widely used GMM consistent estimates. The regression model of CPI inflation in Error! Reference source not found. 4 shows the persistence so, for dynamic macro panel LSDVC (AB) model is selected based on coefficients significance and size of standard error (e.g., see Bruno, 2005; Sung and Park, 2018). The Lag of INF, OP, AD, and TO positively and significantly affect the CPI inflation in selected South Asian economies. Our objective variable shows that one unit increase in CAGAP (increase in CAB concerning CAN) as a percentage of GDP) on average decreases INF by 0.28 percentage point, and the results are in line with Ahmad et al. (2021). According to Lane et al. (2014), positive CAGAP undergo a greater pressure for appreciation of the domestic currency and the relative decline in the aggregate demand that will ultimately hurt the inflation rate. According to the expectation and earlier evidence of the literature, the model results are also (see, e.g., Duarte \& Schnabl, 2014 \& Fuchs, 2015). Three diagnostics tests for LSDVC-AB estimates also produced the expected results.

\section{CONCLUSION}

This study estimated the impact of CAGAP on inflation (CPI) in selected South Asian countries. The result shows that CAGAP significantly and negatively influences the CPI inflation rate while AD, OP, and too positively and significantly affected the CPI inflation rate in the selected period. All the estimates (dynamic LSDV, LSDVC-AH, LSDVC-AB, LSDV-BB generated the same results, but LSDVC-AB is selected, from the three versions of LSDVC (AH, AB, and $\mathrm{BB})$, as baseline regression due to higher significance and lower standard error.

\section{LIMITATIONS AND STUDY FORWARD}

The study used the MB approach of the IMF to estimate CAGAP and did not estimate the CAB elasticities to see the exchange rate gap due to data limitations. Other countries of the region are not included in the study because of data unavailability. Other approaches of IMF as external balance assessment and external sustainability approach with MB can be used in the future, and results can be compared. The study can also be repeated for other regions as well as for sectors.

\section{RECOMMENDATIONS}

Serven and Nguyen (2013) considered that the primary cause of global imbalances is structural distortions and slowchanging factors. They suggested that the target should be structural distortion rather than imbalances. Demand switching policies may also perform better than demand management policies as inflation is significantly determined by the CAGAP. Only nominal exchange rate realignment may not reduce or adjust the size of CAD in the long term. Still, the Adjustment must come from fundamentals, i.e., a correction in domestic imbalances (Obstfeld and Rogoff, 2005).

\section{AUTHORS CONTRIBUTIONS}

This study is based on the Ph.D. dissertation of Sardar Shakeel Ahmad entitled" Estimation of Current Account Gap and its Impact on Economic Growth and Inflation in South Asian Economies under the supervision of Atif Ali Jaffri. Faisal Rana \& Asadullah Khan contributed to arranging the literature review, formatting, and revision of the article.

\section{REFERENCES}

1. Ahmad S. S., Jaffri A. A., Khan A., \& Rana F. (2021). Impact of Current Account Gap on Economic Growth in South Asian Countries, International Journal of Management (IJM), 12(4), 297-303.

2. Al-Eyd, A., Barrell, R., \& Pomerantz, O. (2005). Correcting US Imbalances. National Institute Economic Review, 192(1), 33-39. https://doi.org/10.1177/002795010519200104

3. Baltagi B. H. (2008). Econometric analysis of panel data. Chichester, UK: John Wiley \& Sons. 
4. Blundell, R. and Bond, S. . (2000). GMM estimation with persistent panel data: an application to production functions. Econometric Reviews, 19, 321-340. https://doi.org/10.1080/07474930008800475

5. Borensztein E., Gregorio D.J. (1999). Devaluation and Inflation After Currency Crisis ,International Monetary Fund Universidad de Chile.

6. Bruno, G.S.F. (2005). Estimation and inference in dynamic unbalanced panel-data models with a small number of individuals. The Stata Journal 5(4), 473-500. https://doi.org/10.1177/1536867X0500500401

7. Comunale M. (2015). Current Account and REER misalignments in Central Eastern EU Countries: an update using the Macroeconomic Balance approach. Economics Department, Bank of Lithuania. https://doi.org/10.2139/ssrn.2683310

8. Comunale M. . (2017). A panel VAR analysis of macro-financial imbalances in the EU. ECB Working Paper, No. 2026, ISBN 978-92-899-2748-2.

9. Cusolito , A. P., \& Nedeljkovic, M. (2013). Toolkit For The Analysis Of Current Account Imbalances. World Bank.

10. Dinner, N, \& Kandil, M. . (2011). The Effects of Exchange Rate Fluctuations on Exports: A Sectoral Analysis for Turkey. Journal of International Trade and Economic Development, 20(6). https://doi.org/10.1080 /09638190903137214

11. Duarte P. \& Schnabl G. . (2014). Macroeconomic Policy Making, Exchange Rate Adjustment and Current Account Imbalances in Emerging Markets, CESifo Working Paper, No. 5064, Center for Economic Studies and Ifo Institute (CESifo), Munich.

12. Fuchs p. (2015). Current Account Imbalances: Signs of Adjustment? Review, Federal Reserve Bank of St. Louis, 4(5), 119-128.

13. Gnimassoun, D., \& Mignon, B. . (2013). Current-account adjustments and exchange-rate misalignments. Working Paper 2013/29, CEPII Research Center.

14. Greene E.J. (2018). Macroeconomic Analysis and Policy: A Systematic Approach 2018. Singapore: World Scientific Publishing Co Pte Ltd. https://doi.org/10.1142/10542

15. Holinski N., Kool M.J.C. \& Muysken J., . (2012). Persistent macroeconomic imbalances in the Euro area: causes and consequences. Review, Federal Reserve Bank of St. Louis, 94, 1-20. https://doi.org/10.20955/r.94.1$\underline{20}$

16. Jaffri A.A. (2010). Exchange Rate Pass-through to Consumer Prices in Pakistan: Does Misalignment Matter? The Pakistan Development Review, 49(1), 19-35. https://doi.org/10.30541/v49i1pp.19-35

17. Jha, R., \& Afrin, S. . (2018). Structural Transformation in South Asia. ASARC Working Paper $2018 / 01$. https://doi.org/10.2139/ssrn.3134242

18. Judson A.R., \& Owen L.A. . (1999). Estimating dynamic panel data models: a guide for q macroeconomists. Economics Letters, 65, 9-15. https://doi.org/10.1016/S0165-1765(99)00130-5

19. Kamin B.S. (1997). A Multi-country Comparison of the Linkages between Inflation and Exchange Rate Competitiveness. Bank for International Settlement, Monetary and Economics department (BASLE, WP No.45). https://doi.org/10.2139/ssrn.860684

20. Khan Z. S., Islam S. (2013). The Effects of Remittances on Inflation: Evidence from Bangladesh. Journal of Economics \& Business Research, 19(2), 198-208.

21. Klau, \& Marc. (1998). Exchange Rate Regime and Inflation and Output in Sub-Saharan Countries. Bank for International Settlements, Monetary and Economic Department (BASLE, WP No. 53). https://doi.org/10.213 9/ssrn.857006

22. Khan, K. M., Khan, A. M., Ullah M., Usman, A., Farhat, S., (2020). Closing price determination; extent of manipulation and deterrent strategy formulation: a case of Pakistan Stock Exchange. Journal of Critical Reviews, 7(14), 2689-2705.

23. Lane P.R. \& Milesi-Ferretti M. . (2012). External Adjustment and the Global Crisis. . Journal of International Economics, 88(2), 252-265. https://doi.org/10.1016/j.jinteco.2011.12.013

24. Lane R.P., and Milesi-Ferretti M.G. . (2014). Global Imbalances and External Adjustment after the Crisis 2014. IMF Working Paper Research Department WP/14/151. https://doi.org/10.5089/9781498339216.001

25. Medina L., Prat, \& Thomas J. (2010). Current Account Balance Estimates for Emerging Market Economies. International Monetary Fund, IMF WP/10/43. https://doi.org/10.5089/9781451962994.001

26. Obstfeld, M., \& Rogoff, K. S. (2005). Global Current Account Imbalances and Exchange Rate Adjustments. Brookings Papers on Economic Activity, Economic Studies Program, The Brookings Institution, 36(1), 67-146. https://doi.org/10.1353/eca.2005.0020

27. Pyhrr S., Born W., and Webb J. (1990). Development of a Dynamic Investment Strategy under Alternative Inflation Cycle Scenarios. Journal of Real Estate Research, 5(2), 177-193. https://doi.org/10.1080/10 $\underline{835547.1990 .12090617}$

28. Rahman, J. (2008). Current Account Developments in the New Member States of the European Union: Equilibrium, Excess and EU-Phoria. . IMF Working Paper WP/08/92, International Monetary Fund. https://doi.org/10.5089/9781451869538.001

29. Sbordone A. M. (2007). Inflation persistence: Alternative interpretations and policy implications. Journal of Monetary Economics, Elsevier, 54(5), 1311-1339. https://doi.org/10.1016/j.jmoneco.2007.06.007 
30. Serven L. \& Nguyen H., . (2013). Global Imbalances: Origins and Prospects. World Bank Research Observer, World Bank Group, 28(2), 191-219. https://doi.org/10.1093/wbro/lkt002

31. Shaikh, S., Channar, P., Shaikh, M., \&, Ullah, M., (2021). Financial constraints and listed sugar mills on Pakistan Stock Exchange. International Journal of Management, 12(3), 70-76. https://doi.org/10.2927 0/JBS.12.2(2018).0118

32. Sung, B. \& Park, S.-D. (2018). Who Drives the Transition to a Renewable-Energy Economy? Multi-Actor Perspective on Social Innovation. Sustainability MDPI, 10, 448.

33. Trabelsi E. (2016). What effects exert Economic Globalization and Central Bank Transparency on inflation of OECD countries? An Application of LSDVC Estimator on a Dynamic Panel Model. Working Papers hal01157387, HAL. https://doi.org/10.3390/su10020448

34. Tung T. L., Ly M.T.P., Nhu Q.T.P, Thanh T. P., Anh. (2015). The Impact of Remittance Inflows on Inflation: Evidence in Asian and the Pacific Developing Countries. Journal of Applied Economic Sciences (JAES), 37, 1076-1080.

35. Ullah, M., Shaikh, M., Channar, P., \& Shaikh, S., (2021). Financial forecasting: an individual perspective. International Journal of Management, 12(3), 60-69.

36. World Bank. (2019). South Asia Economic Focus, Fall 2019 - Globalization Backlash. Washington DC: The World Bank.

37. Yurdakul, F., \& Ucar, B. . (2015). The Relationship Between Current Deficit and Economic Growth: An Empirical Study on Turkey. Science Direct Procedia Economics and Finance 26, 101-108. https://doi.org/10 $.1016 / \mathrm{S} 2212-5671(15) 00885-0$ 